\title{
Using the Combined Fenton-MBR Process to Treat Cutting Fluid Wastewater
}

\author{
Qian Zhang ${ }^{1}$, ChangJiang Yu ${ }^{1}$, Jie Fang ${ }^{1}$, HaiYang Xu ${ }^{1}$, \\ QianLi Jiang ${ }^{1}$, ShengKe Yang ${ }^{1,2 *}$, WenKe Wang ${ }^{1,2}$ \\ ${ }^{1}$ Key Laboratory of Subsurface Hydrology and Ecology in Arid Areas, Ministry of Education, \\ Chang'an University, Xi'an 710054, P.R. China \\ ${ }^{2}$ Shanxi Key Laboratory of Exploration and Comprehensive Utilization of Mineral Resources, \\ Xi'an 710054, P.R. China
}

Received: 7 November 2016

Accepted: 2 January 2017

\begin{abstract}
Cutting fluid wastewater is a highly concentrated organic effluent generated in the production of silicon water. Because the wastewater that contains synthetic organic compounds is characterized by high COD content, complex components, and poor biodegradability, it is absolutely formidable to be fully treated using one method. Therefore, the combined Fenton-MBR process was developed and explored in this trial, in which some organic compounds such as polyethylene glycol and surfactants can be broken to little pieces by Fenton oxidation and subsequently treated by the MBR process. The operating parameters were tested and optimized respectively, and the process mechanism was revealed as well. Under optimal operating conditions of Fenton oxidation (COD concentration of 2,500 mg/L, reaction temperature of $30^{\circ} \mathrm{C}, \mathrm{pH}$ of $3.0, \mathrm{Fe}^{2+}$ dosage of $20 \mathrm{mmol} / \mathrm{L}, \mathrm{H}_{2} \mathrm{O}_{2}$ dosage of $250 \mathrm{mmol} / \mathrm{L}$, and treatment time of $3 \mathrm{~h}$ ) and MBR system (HRT of $8 \mathrm{~h}$, DO of $1 \mathrm{mg} / \mathrm{L}$ ), COD removal efficiency could reach 97\%, and the effluent COD was ultimately reduced to $100 \mathrm{mg} / \mathrm{L}$. The results demonstrated that the combined Fenton-MBR process can solve the defects of MBR, which is arduous to degrade synthetic organic compounds, improving the biodegradability of wastewater and the efficiency of contaminant removal.
\end{abstract}

Keywords: cutting fluid wastewater, combined Fenton-MBR, operational parameters, COD removal efficiency

\section{Introduction}

In the case of the current energy shortage and environmental pollution, solar energy has become the focus of energy development in much of the world [1-3]. However, a large amount of wastewater generated by the

*e-mail: ysk110@126.com extensive use of cutting fluid originates from silicon wafer operations, and the cutting fluid wastewater is known to have high COD content, complex components, and poor biodegradability. Nowadays, with the increasingly stringent standards of effluent, most sewage treatment facilities of enterprises have found it difficult to meet the standards. Therefore, research of new processing technology is urgently needed.

Cutting fluid wastewater belongs to the high concentration of refractory organic wastewater, which 
contains large amounts of complex organic components, thus how to deal with it is a difficult issue. Physicalchemical treatment and biological treatment are mainly used to treat highly concentrated organic wastewater. The principle of physical-chemical treatment, including catalytic oxidation [4], incineration [5], solvent extraction [6], chemical flocculation [7-8], and the electro-chemical method [9]. However, the physical-chemical method is not only costly, but difficult to treat. Therefore, it is usually used as a pre-processing method. The primary methods of biological treatment are activated carbon adsorption [10], membrane separation [11-12], biological treatment technology [13], and the advanced oxidation process [1415]. The reactors are mainly upflow anaerobic sludge blanket reactors (UASB) [16], expanded granular sludge beds (EGSB) [17], and membrane bio-reactors (MBR) [18-20].

Scholars such as Ipek et al. [21], Zazo et al. [22], and Yang [23] have reported the treatment of carpet dyeing wastewater, phenol wastewater, and municipal landfill leachate by Fenton process, respectively, and got the most favorable conditions, but the overall cost is high. Sheldon et al. [24] and Pretel et al. [25] studied the treatment of soft drink industry wastewater and the moderate-/high-loaded urban wastewater treatment using MBR technology. However, because of the low initial concentration, the processing efficiency is low. $\mathrm{Xu}$ et al. [26], Perez et al. [27], and Sanchez et al. [28] attempted to combine Fenton with the MBR process to treat wastewater. $\mathrm{Xu}$ et al. [26] reported the avermectin fermentation wastewater reclamation using the Fenton-Anoxic-Oxic/ MBR process, discovering that under the most favorable conditions for Fenton oxidation, the average removal rates are $84.3 \%, 79.4 \%$, and $72.3 \%$ for COD, ammonia, and TN, respectively. Perez et al. [27] investigated a combined system for removing the fungicide thiabendazole (TBZ) in a simulated agro-food industrial wastewater. Results showed that combined MBR and the Fenton/photo-Fenton process is a good way to remove TBZ. Sanchez et al. [28] reported the photo-Fenton/MBR combined process to treat industrial ecotoxic wastewater, showing that the combination process was conducive to cost reduction. At present, few studies have been conducted on a combined process to treat wastewater that contains synthetic organic compounds.

Most solar energy enterprises currently use the traditional "aerobic biochemical" processing method. It is hard to reach the processing standard using a single conventional method on account of the cutting liquid wastewater containing highly concentrated organic compounds such as polyethylene glycol and surfactants, which reach up to $2,000-4,000 \mathrm{mg} / \mathrm{L}$. Considering that the Fenton method is suitable for the degradation of highly concentrated organic pollutants and can partially oxidize and remove organic substances, the organic compounds can be turned into pieces by Fenton reagent to improve biological degradability. In addition to the low operating costs of the MBR method and the advantages of the MBR method that can be used for the degradation of low-concentration organic pollutants, the treatment of cutting fluid wastewater is studied in this paper, which carries on the research of the Fenton-MBR combined process. Some technological advances provide theoretical guidance and technical support for industrial application, as well as reducing pollution to the environment in the process of polysilicon production and satisfying the enterprise sewage discharge standards.

\section{Materials and Methods}

Reagents:

- Ferrous sulfate $\left(\mathrm{FeSO}_{4} \cdot 7 \mathrm{H}_{2} \mathrm{O}\right.$, A.R Xi'an Chemical Reagent Factory).

- Hydrogen peroxide $\left(\mathrm{H}_{2} \mathrm{O}_{2}, 30 \%\right.$, A.R Tianjin Beilian Fine Chemicals Development Co. Ltd.).

- Sulfuric acid and sodium hydroxide (A.R Beijing North Fine Chemicals Co. Ltd.).

- Polyethylene glycol 4000 (PEG, C.P Tianjin Kermel Chemical Reagent Co. Ltd.).

Equipment:

- MBR equipment and membrane module (Jiangsu Dartfar Membrane Technology Co. Ltd.). The MBR device is composed of a mixed-water distribution system, MBR treatment system, effluent water collection system, and controlling system. The MBR system uses immersion flat membrane, which is established by the built-in way, and the membrane elements consist of ultra micro filtration membrane, diversion cloth, and deflector.

- DELTA -320 pH meter (Mettler Toledo Instruments (Shanghai) Co. Ltd.).

- CS101-AB electrothermal blowing dry box (Chongqing Test Equipment Factory).

- HH-4 digital display thermostatic bath pot (Changzhou State Electrical Appliance Co. Ltd.).

- 5B-3A COD rapid measurement instrument (Lanzhou LianHua Environmental Protection Technology Co. Ltd.).

Wastewater

The cutting fluid wastewater used in this study was obtained from $\mathrm{Xi}$ 'an longji silicon material Co. Ltd., with a high initial concentration of COD, and the main pollutants are polyethylene glycol, surfactants, emery and monocrystalline silicon powder, etc. (Table 1).

\section{Experimental Methods}

\section{Fenton Process Procedure}

A certain amount of the samples were taken in a conical flask. The $\mathrm{pH}$ adjustment was then carried out to the optimum level with $1 \mathrm{~mol} / \mathrm{L}$ sulphuric acid $\left(\mathrm{H}_{2} \mathrm{SO}_{4}\right)$ and $1 \mathrm{~mol} / \mathrm{L}$ sodium hydroxide $(\mathrm{NaOH})$. Required amounts of $\mathrm{FeSO}_{4} \cdot 7 \mathrm{H}_{2} \mathrm{O}$ and $\mathrm{H}_{2} \mathrm{O}_{2}$ were successively added to the sample, and the reaction lasted $3 \mathrm{~h}$ on a constant temperature oscillator. After the reaction, the solution $\mathrm{pH}$ was adjusted 
Table 1. Characteristics of wastewater.

\begin{tabular}{|c|c|c|c|c|c|c|}
\hline & $\begin{array}{c}\mathrm{COD} \\
(\mathrm{mg} / \mathrm{L})\end{array}$ & $\begin{array}{c}\mathrm{SS} \\
(\mathrm{mg} / \mathrm{L})\end{array}$ & $\mathrm{pH}$ & $\begin{array}{c}\text { Surfactant } \\
(\mathrm{mg} / \mathrm{L})\end{array}$ & $\begin{array}{c}\text { Chroma } \\
(\mathrm{PCU})\end{array}$ & $\begin{array}{c}\text { Conductivity } \\
(\mu \mathrm{S} / \mathrm{cm})\end{array}$ \\
\hline This study & 2500 & 1356 & 4.35 & 755.6 & 376 & 243.5 \\
\hline Reference & $1,000-5,000$ & $1,000-2,000$ & $3-5$ & $500-1,000$ & $200-700$ & $200-300$ \\
\hline
\end{tabular}

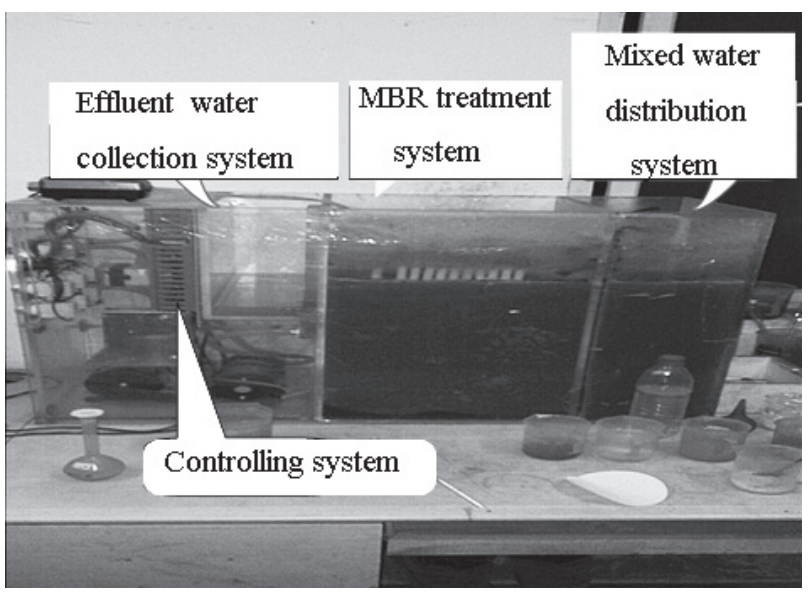

Fig. 1. MBR reaction device.

to alkalinity using $1 \mathrm{~mol} / \mathrm{L} \mathrm{NaOH}$ in order to make excess iron ion in water samples to form precipitation. Following a certain time of sedimentation, the COD value of effluent was determined using the supernatant.

\section{MBR Process Procedure}

We used the wastewater treated by Fenton oxidation to fill an MBR reactor (Fig. 1) with a certain velocity gradually at the inlet end until the flat membrane was submerged, then testing machine, culturing bacteria, and domestication. After $48 \mathrm{~h}$ the reactor started up and operated under different HRT and dissolved oxygen concentration with timekeeping. During the experiment, the sample was extracted from the suction port at different times according to the design, and the COD value was determined using the sample.

\section{Results}

Fenton Process for the Treatment of Cutting Fluid Wastewater

\section{Effect of $\mathrm{Fe}^{2+}$ Dosage}

The effect of $\mathrm{Fe}^{2+}$ dosage (i.e., 0, 2, 5, 10, 20, 30, and $50 \mathrm{mmol} / \mathrm{L}$ ) on COD removal efficiency was examined thoroughly, while keeping the COD concentration, reaction temperature, $\mathrm{pH}, \mathrm{H}_{2} \mathrm{O}_{2}$ dosage, and treatment time at $2,500 \mathrm{mg} / \mathrm{L}, 30^{\circ} \mathrm{C}, 3.0,250 \mathrm{mmol} / \mathrm{L}$, and $3 \mathrm{~h}$, respectively. As seen in Fig. 2, as $\mathrm{Fe}^{2+}$ doses were increased from 0 to $20 \mathrm{mmol} / \mathrm{L}$, COD removal

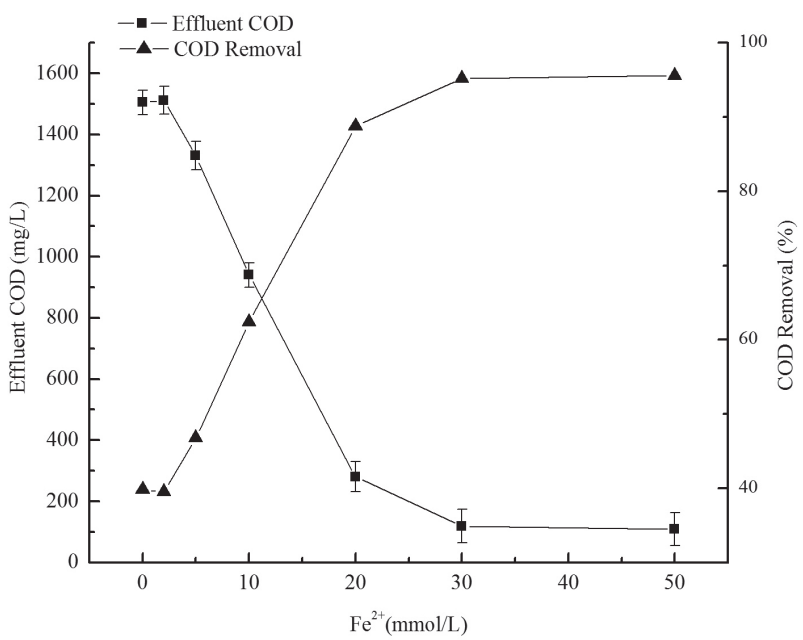

Fig. 2. Effect of $\mathrm{Fe}^{2+}$ dosage on $\mathrm{COD}$ removal $\left(\mathrm{H}_{2} \mathrm{O}_{2}=\right.$ $250 \mathrm{mmol} / \mathrm{L} ; \mathrm{C}_{0}=2500 \mathrm{mg} / \mathrm{L} ; \mathrm{t}=3 \mathrm{~h} ; \mathrm{T}=30^{\circ} \mathrm{C} ; \mathrm{pH}=3$ ).

efficiencies increased from 39.82 to $88.77 \%$. Hence, it can be said that higher ferrous doses lead to the generation of more $\mathrm{OH} \bullet$ radicals and not only made the redox reaction complete but also caused coagulation, resulting in improved COD removal [21]. However, at higher doses of $\mathrm{Fe}^{2+}$, excessive $\mathrm{Fe}^{2+}$ will capture and consume $\mathrm{OH} \bullet$ radicals and reduce the production rate of $\mathrm{OH} \bullet$, as well as decrease the amount of the effective part of $\mathrm{OH} \bullet$. COD removal efficiency remained almost constant, indicating that $\mathrm{Fe}^{2+}$ became the limiter for the reaction. According to the experimental condition and considering the economic factors, the optimal dosage of $\mathrm{Fe}^{2+}$ is $20 \mathrm{mmol} / \mathrm{L}$.

\section{Effect of $\mathrm{H}_{2} \mathrm{O}_{2}$ Dosage}

The effect of dosage (i.e., 0, 50, 100, 150, 200, 250, 300,350 , and $400 \mathrm{mmol} / \mathrm{L}$ ) on COD removal efficiency was evaluated while keeping the COD concentration, reaction temperature, $\mathrm{pH}, \mathrm{Fe}^{2+}$ dosage, and treatment time at $2,500 \mathrm{mg} / \mathrm{L}, 30^{\circ} \mathrm{C}, 3.0,20 \mathrm{mmol} / \mathrm{L}$, and $3 \mathrm{~h}$, respectively. The results obtained are presented graphically in Fig. 3.

Fig. 3 shows that the removal rate of COD was as low as $39.50 \%$ when $\mathrm{H}_{2} \mathrm{O}_{2}$ dosage was zero, since the reaction only depended on ferrous ion to form coagulation at this time. The removal rate of COD was increased to $86.41 \%$ when $\mathrm{H}_{2} \mathrm{O}_{2}$ was raised to $250 \mathrm{mmol} / \mathrm{L}$. When the dosage of $\mathrm{H}_{2} \mathrm{O}_{2}$ increased, the amount of $\mathrm{OH} \bullet$ also increased, and the removal rate of pollutants improved accordingly. However, when $\mathrm{H}_{2} \mathrm{O}_{2}$ doses over a critical value, no 


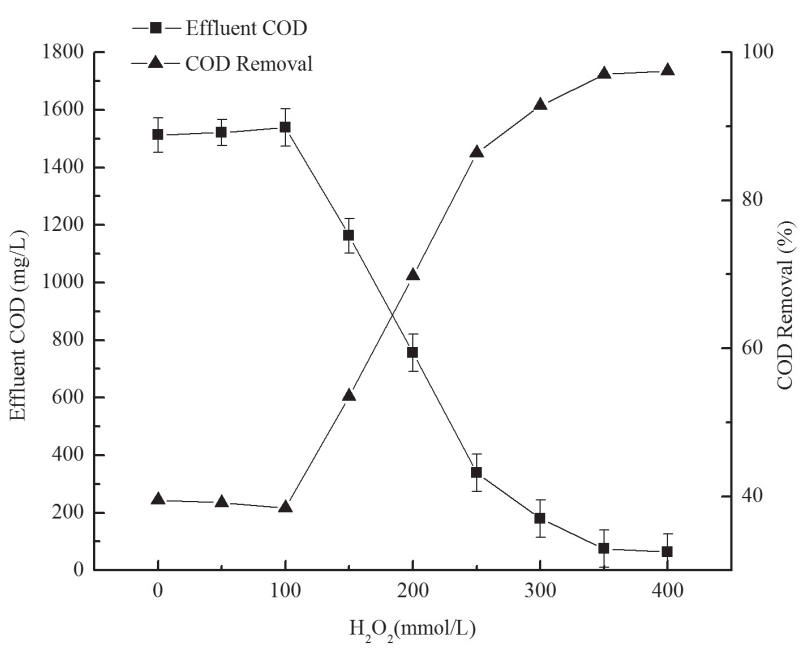

Fig. 3. Effect of $\mathrm{H}_{2} \mathrm{O}_{2}$ dosage on $\mathrm{COD}$ removal $\left(\mathrm{Fe}^{2+}=\right.$ $20 \mathrm{mmol} / \mathrm{L} ; \mathrm{C}_{0}=2500 \mathrm{mg} / \mathrm{L} ; \mathrm{t}=3 \mathrm{~h} ; \mathrm{T}=30^{\circ} \mathrm{C} ; \mathrm{pH}=3$ ).

further increase in COD removal was observed. Because the excess $\mathrm{H}_{2} \mathrm{O}_{2}$ will react with $\mathrm{OH} \bullet$ to make the highactivity $\mathrm{OH} \bullet$ into a low-activity $\mathrm{OOH} \bullet$, which not only consumes highly active $\mathrm{OH} \bullet$ but also leads to the decrease of the oxidation ability of the system, ultimately result in the decline of pollutant degradation rate. Considering the economic factors, the optimal dosage of $\mathrm{H}_{2} \mathrm{O}_{2}$ is $250 \mathrm{mmol} / \mathrm{L}$.

\section{Effect of Initial Concentration}

Effect of initial concentration on COD removals was examined by changing the COD concentration of the samples between 1,000 and 5,000 mg/L (i.e., 1,000, 2,000, $2,500,3,000,4,000$, and $5,000 \mathrm{mg} / \mathrm{L}$ ), while the other operating conditions were reaction temperature of $30^{\circ} \mathrm{C}$, $\mathrm{pH}$ of $3.0, \mathrm{Fe}^{2+}$ dosage of $20 \mathrm{mmol} / \mathrm{L}, \mathrm{H}_{2} \mathrm{O}_{2}$ dosage of $250 \mathrm{mmol} / \mathrm{L}$, and treatment time of $3 \mathrm{~h}$.

As the initial concentration of the samples increased from 1,000 to $2,500 \mathrm{mg} / \mathrm{L}$, COD removal efficiencies decreased from 96.73 to $93.05 \%$. However, when the initial concentration increased to $5,000 \mathrm{mg} / \mathrm{L}$, the removal rate of COD significantly decreased from 93.05 to $77.25 \%$. According to the experimental conditions, the initial concentration of COD is chosen to be $2,500 \mathrm{mg} / \mathrm{L}$ in the following experiment.

\section{Effect of Treatment Time}

Under optimal conditions (COD concentration of $2,500 \mathrm{mg} / \mathrm{L}$, reaction temperature of $30^{\circ} \mathrm{C}$, $\mathrm{pH}$ of $3.0, \mathrm{Fe}^{2+}$ dosage of $20 \mathrm{mmol} / \mathrm{L}$, and $\mathrm{H}_{2} \mathrm{O}_{2}$ dosage of $250 \mathrm{mmol} / \mathrm{L}$ ), the cutting fluid wastewater was treated between 0 and 240 min (i.e., 0, 30, 60, 90, 120, 150, 180, 210, and $240 \mathrm{~min}$ ) by the Fenton process in order to examine the effect of treatment time on COD removal.

The experimental data shows that COD removal efficiency rapidly increased from 41.44 to $66.1 \%$ after $180 \mathrm{~min}$ treatment. However, a further increase of treatment time did not obviously enhance pollutant removal efficiency. When the reaction time reaches $180 \mathrm{~min}$, although the reaction is still in process, the degradation rate of COD is basically unchanged. Considering the degradation rate and economic benefit, the optimal treatment time is $3 \mathrm{~h}$. These phenomena are mainly attributed to the following reasons. On the one hand, the solution only contains $\mathrm{Fe}^{2+}$ at the beginning of the reaction, which is slow. However, $\mathrm{Fe}^{2+}$ leads to the generation of $\mathrm{OH} \bullet$ radicals by catalyzing the decomposition of $\mathrm{H}_{2} \mathrm{O}_{2}$, and $\mathrm{OH} \bullet$ radicals not only oxidize the organic compounds but also improve COD removal efficiency as the reaction goes on. On the other hand, there is no more $\mathrm{H}_{2} \mathrm{O}_{2}$ for catalytic decomposition with the extension of reaction time, resulting in little increase of COD removal rate.

\section{Effect of $p H$ Value}

Under optimal conditions (COD concentration of $2,500 \mathrm{mg} / \mathrm{L}$, reaction temperature of $30^{\circ} \mathrm{C}, \mathrm{Fe}^{2+}$ dosage of $20 \mathrm{mmol} / \mathrm{L}, \mathrm{H}_{2} \mathrm{O}_{2}$ dosage of $250 \mathrm{mmol} / \mathrm{L}$, and treatment time of $3 \mathrm{~h}$ ), the $\mathrm{pH}$ adjustment was carried out between 1.5 and 6 (i.e., 1.5, 2.0, 2.5, 3.0, 3.5, 4.0, 5.0, and 6.0) with $1 \mathrm{~mol} / \mathrm{L}$ sulphuric acid $\left(\mathrm{H}_{2} \mathrm{SO}_{4}\right)$ and $1 \mathrm{~mol} / \mathrm{L}$ sodium hydroxide $(\mathrm{NaOH})$ in order to examine the effect of $\mathrm{pH}$ value on COD removal (Fig. 4).

According to Fig. 4, when $\mathrm{pH}$ increased from 1.5 to 3, the COD removal efficiency was enhanced rapidly from 40.86 to $66.1 \%$. And then it further decreased to $39.91 \%$ when the $\mathrm{pH}$ increased from 3 to 5 . Therefore, according to the experiment, the optimal $\mathrm{pH}$ value should be 3 .

COD removal by oxidation, coagulation, and overall process depended strongly on initial $\mathrm{pH}$ [23]. At high $\mathrm{pH}$ $(>4)$, the generation of $\mathrm{OH} \bullet$ gets slower because of the formation of the ferric hydroxo complexes; the complexes would further form $\left[\mathrm{Fe}(\mathrm{OH})_{4}\right]$ when the $\mathrm{pH}$ value is higher than 9.0 [29]. On the other hand, at very low $\mathrm{pH}$ values $(<2.0)$ the reaction is slowed due to the formation of complex species $\left[\mathrm{Fe}\left(\mathrm{H}_{2} \mathrm{O}\right)_{6}\right]^{2+}$, which react more slowly with peroxide compared to $\left[\mathrm{Fe}(\mathrm{OH})\left(\mathrm{H}_{2} \mathrm{O}\right)_{5}\right]^{2+}$. In

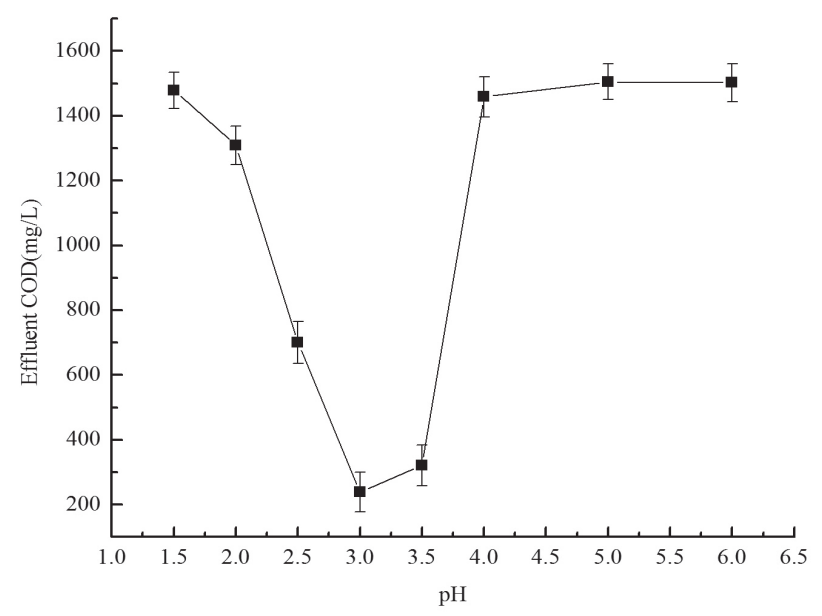

Fig. 4. Effect of the $\mathrm{pH}$ value $\left(\mathrm{Fe}^{2+}=20 \mathrm{mmol} / \mathrm{L} ; \mathrm{H}_{2} \mathrm{O}_{2}=\right.$ $250 \mathrm{mmol} / \mathrm{L} ; \mathrm{C}_{0}=2500 \mathrm{mg} / \mathrm{L} ; \mathrm{T}=30^{\circ} \mathrm{C} ; \mathrm{t}=3 \mathrm{~h}$ ). 
addition, the peroxide gets solvated in the presence of a high concentration of $\mathrm{H}^{+}$ion to form stable oxonium ion $\left[\mathrm{H}_{3} \mathrm{O}_{2}\right]^{+}$. An oxonium ion makes peroxide electrophilic to enhance its stability and presumably substantially reduces the reactivity with $\mathrm{Fe}^{2+}$ ion [30]. Therefore, the initial $\mathrm{pH}$ value has to be in the acidic range (2-4) in order to generate the maximum amount of $\mathrm{OH} \bullet$ to oxidize organic compounds [21, 23, 29, 31-32].

\section{Effect of Reaction Temperature}

A temperature range of $15-40^{\circ} \mathrm{C}$ (i.e., $10,15,20,25$, 30,35 , and $40^{\circ} \mathrm{C}$ ) was studied in order to observe the effect of temperature on COD removal efficiency, while keeping the COD concentration, $\mathrm{pH}, \mathrm{Fe}^{2+}$ dosage, $\mathrm{H}_{2} \mathrm{O}_{2}$ dosage, and treatment time at 2,500 $\mathrm{mg} / \mathrm{L}, 3.0,20 \mathrm{mmol} / \mathrm{L}$, $250 \mathrm{mmol} / \mathrm{L}$, and $3 \mathrm{~h}$, respectively.

According to the experimental data, when the temperature increased from 10 to $30^{\circ} \mathrm{C}$ the COD removal efficiency was enhanced rapidly from 39.47 to $92.44 \%$. However, a further increase in temperature did not obviously enhance pollutant removal efficiency. Therefore, the optimal temperature should be $30^{\circ} \mathrm{C}$ according to experimental and economic factors.

Reaction temperature is an important factor to influence the oxidation of Fenton. A change in temperature can result in the change of ferrous ion in concentration and production of $\mathrm{OH} \bullet$ in water samples, which influence the oxidation and degradation ability of Fenton reagent. When the reaction temperature is too low, it will affect the reaction rate of the Fenton process, and the system has a relatively low oxidative capacity lacking hydroxyl radicals. When the reaction temperature is too high, although it is conducive to the Fenton reaction, the $\mathrm{H}_{2} \mathrm{O}_{2}$ is unstable and easily decomposed to produce hydrogen and oxygen when heated. High temperature will cause thermal decomposition of $\mathrm{H}_{2} \mathrm{O}_{2}$, reduce the amount of $\mathrm{H}_{2} \mathrm{O}_{2}$ in the system, result in the decrease of oxidative capacity, and ultimately hinder the degradation of COD in water samples.

\section{MBR Process for the Treatment of Cutting Fluid Wastewater}

In this part, the experiments were carried out using the MBR process to study the removal of COD and determine the optimum operating conditions in cutting fluid wastewater through two aspects, which are hydraulic retention time (HRT) and dissolved oxygen (DO) concentration. The influent COD value was controlled among $600-800 \mathrm{mg} / \mathrm{L}$ in the experiment while the sludge concentration was controlled among 8,000-10,000 mg/L. Through testing the machine, culturing the bacteria, domestication, and operation, the reactor started up.

\section{Effect of HyDraulic Retention Time (HRT)}

In this experiment, in order to observe the effect of HRT on COD removal efficiency throughout the MBR

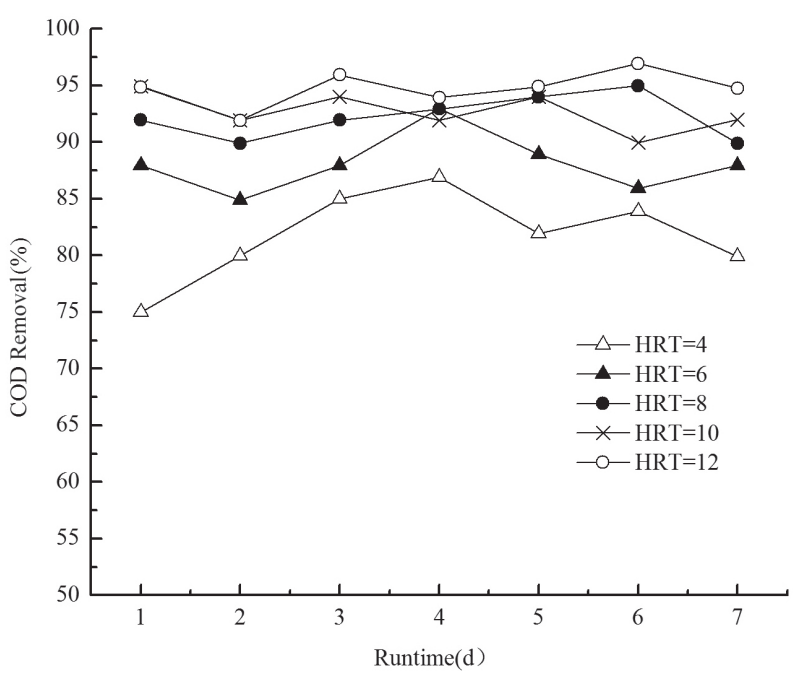

Fig. 5. Effect of HRT on COD removal.

process, the HRT was carried out between 4 and 12 (i.e., $4,6,8,10$, and $12 \mathrm{~h}$ ), while maintaining other conditions and determining the samples after the reactor ran a cycle (Fig. 5).

As shown in Fig. 5, COD removal efficiency increased steadily with the extension of HRT, and the removal rate was over $90 \%$ when HRT was $8 \mathrm{~h}, 10 \mathrm{~h}$, and $12 \mathrm{~h}$, as well as the effluent COD can reach the water standard. When the system was under the conditions of short HRT, the fast bacteria breeding and high activity can cushion the impact of high load to some extent, but increasing the content of effluent COD. Along with the decreases of organic load, this situation slowly improved with long HRT. When the sludge load drops to a certain extent, carbon source becomes the main factor that restricts the growth of sludge. Longer HRT will inhibit sludge activity and reduce the amount of sludge, which is not helpful in the removal of COD. Consequently, the HRT was chosen as $8 \mathrm{~h}$.

\section{Effect of Dissolved Oxygen (DO) Concentration}

The HRT of $8 \mathrm{~h}$ was selected according to the above study. In order to observe the effect of dissolved oxygen (DO) concentration on COD removal efficiency throughout the MBR process, the dissolved oxygen (DO) concentration was carried out between 1 and 5 (i.e., 1,3 , and $5 \mathrm{mg} / \mathrm{L}$ ) while maintaining other conditions and determining the samples after the reactor ran a cycle (Fig. 6).

Fig. 6 shows that the removal effect of COD is on the rise with the increase of the dissolved oxygen concentration. In general, the removal rate of COD can reach a good level in the above cases, and the effluent COD can reach the discharge standard. The aerobic bacteria can remove most organic matter. When the concentration of dissolved oxygen is low, environmental hypoxia will appear in part of the reactor, the activity of aerobic bacteria will be inhibited, and the removal rate will be pretty low. When the concentration of dissolved oxygen 


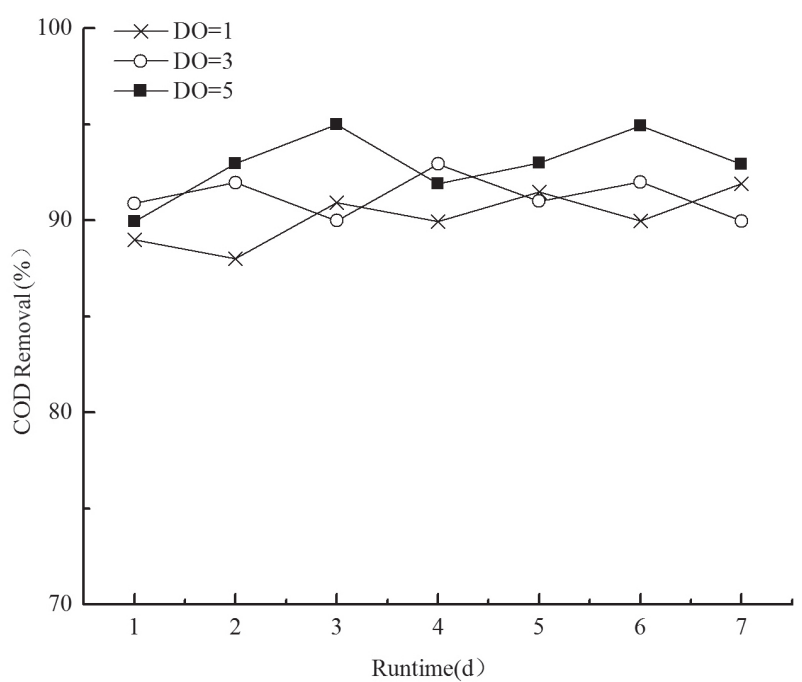

Fig. 6. Effect of dissolved oxygen (DO) concentration on COD removal.

increases, the activity of aerobic bacteria also is enhanced, the removal efficiency of the system increases, and the removal rate lifts from 90 to $95 \%$. Taking into account the fact that increasing the dissolved oxygen concentration will consume power and for economic considerations, dissolved oxygen concentration was selected as $1 \mathrm{mg} / \mathrm{L}$.

\section{Fenton-MBR Combined Process for Treating Cutting Fluid Wastewater}

According to engineering practices, this experiment carried out a test using the Fenton-MBR combined process for the treatment of cutting fluid wastewater. The specific procedure was taken as follows: After removing large particles of impurities by pretreatment, the cutting fluid wastewater was treated first by using the Fenton method under optimum reaction conditions (COD concentration of $2,500 \mathrm{mg} / \mathrm{L}$, reaction temperature of $30^{\circ} \mathrm{C}, \mathrm{pH}$ of $3.0, \mathrm{Fe}^{2+}$ dosage of $20 \mathrm{mmol} / \mathrm{L}, \mathrm{H}_{2} \mathrm{O}_{2}$ dosage of $250 \mathrm{mmol} / \mathrm{L}$, and treatment time of $3 \mathrm{~h}$ ). Then the filtration was needed to remove the precipitation, and the $\mathrm{pH}$ was adjusted to a range of 6.5-8.5. Next, we used the MBR method for processing and controlling the optimum reaction conditions (the HRT of $8 \mathrm{~h}$ and the dissolved oxygen concentration of $1 \mathrm{mg} / \mathrm{L}$ ). Finally, the treatment efficiencies of cutting fluid wastewater were analyzed and evaluated by COD (Table 2).
Table 2 represents the removal of COD as relatively low in the first two days after the start of the operation, probably due to the unstable operation of the system. With the extension of time, the operation of the system was stabilized by degrees, and the removal rate of COD increased gradually, ultimately reaching 97\%. The experimental results can satisfy the discharge standards of wastewater.

\section{Discussion}

\section{Fenton Process}

Based on the correlative references of the Fenton process to treat wastewater, as shown in Table 3, under the different optimal conditions, the COD removal efficiency was between 47.1 and $84 \%$. The COD removal efficiency of cutting fluid wastewater was as high as $93.05 \%$ in this study, which was higher than the literature and close to the COD removal efficiency of chelating the optimization Fenton process by Mohsen Moussav et al. [38]. Table 3 also represents the optimal conditions of $\mathrm{pH}$ at about 3 , and the optimal value of $\mathrm{H}_{2} \mathrm{O}_{2} / \mathrm{Fe}^{2+}$ appears to be a bigger difference in different literature. The reason may be due to the different types and components of wastewater, the varying degree of oxidation of organic pollutants, and the different initial concentrations of COD. Exactly speaking, the oxidation degree is associated with the oxidation potential of pollutants. Therefore, in the future, the related ratio between hydrogen peroxide and iron should be paid more attention to when dealing with different pollutants by the Fenton process.

\section{MBR Process}

There are also several correlative literatures reported on the MBR process treating wastewater. The indicators affecting the MBR process may be DO, HRT, SRT, and so on. However, most of the literature is more focused on HRT. The diversity of processing methods have different HRTs [39-41]. Daniel María González-Pérezet al. [39] carried out the MBR process to treat urban wastewater, when the full-scale MBR system was in continuous operation for 530 days at high SRT and HRT, the COD removal rate for the entire period was over $98 \%$. Daniel only considered the influence of SRT and HRT to the MBR process, and the efficiency is low, with $96 \mathrm{~h}$ of HRT. Therefore the

Table 2. Effect of Fenton-MBR combined process on COD removal.

\begin{tabular}{|c|c|c|c|c|c|c|c|}
\hline Runtime (d) & 1 & 2 & 3 & 4 & 5 & 6 & 7 \\
\hline Initial influent COD (mg/L) & 2,368 & 2,528 & 2,673 & 2,547 & 2,801 & 2,612 & 2,489 \\
\hline Intermediate effluent COD (mg/L) & 862 & 846 & 837 & 789 & 813 & 792 & 754 \\
\hline Final effluent COD (mg/L) & 143 & 105 & 92 & 86 & 74 & 67 & 72 \\
\hline Removal rate of COD & 93.96 & 95.85 & 96.56 & 96.62 & 97.36 & 97.43 & 97.11 \\
\hline
\end{tabular}


Table 3. COD removal efficiency in the optimal conditions of the Fenton process.

\begin{tabular}{|c|c|c|c|c|c|c|c|}
\hline $\mathrm{H}_{2} \mathrm{O}_{2} / \mathrm{Fe}^{2+}$ & $\mathrm{C}_{0}(\mathrm{mg} / \mathrm{L})$ & $\mathrm{T}(\mathrm{min})$ & $\mathrm{pH}$ & $\mathrm{T}\left({ }^{\circ} \mathrm{C}\right)$ & Wastewater & $\begin{array}{c}\text { COD } \\
\text { Removal } \\
(\%)\end{array}$ & References \\
\hline $7.6 / 1$ & 2,500 & 180 & 3 & 30 & cutting fluid & 93.05 & This study \\
\hline $12.4 / 1$ & 180 & 3 & 30 & sugarcane vinasse & 54.6 & $\begin{array}{c}\text { Lígia F. Guerreiro } \\
\text { et al.(2016) [33] }\end{array}$ \\
\hline $10 / 1$ & 3,133 & 120 & 3 & 30 & retting flax & 80 & $\begin{array}{c}\text { Sohair I. Abou-Elela et al. } \\
\text { (2016) [34] }\end{array}$ \\
\hline $1 / 1$ & 250 & & 3 & & papermaking & 73.4 & $\begin{array}{c}\text { Shuai Fang et al. } \\
(2105)[35]\end{array}$ \\
\hline $40 / 1$ & & 114 & 3.14 & & $\begin{array}{c}\text { dry-spun acrylic fiber } \\
\text { manufacturing }\end{array}$ & 47.1 & $\begin{array}{c}\text { Jian Wei et al. } \\
\text { (2014) [36] }\end{array}$ \\
\hline
\end{tabular}

high removal rate of COD is probably because of the long HRT. Nevertheless, the effect of DO on the MBR process was also considered in this study. When we chose the best condition of DO, the HRT was chosen as $8 \mathrm{~h}$ and the COD removal rate was over $90 \%$ entirely.

\section{Fenton-MBR Combined Process}

According to the correlative literature about treating high-concentration organic wastewater, it is known that when combining the Fenton or MBR method with other methods, COD removal rate was lower than the removal efficiency of the Fenton-MBR combined process in this study.

Haifeng Zhuang et al. [42] proposed a novel integration of heterogeneous Fenton oxidation to treat coal fly ash/ sewage sludge carbon composite, and COD removal efficiency was 74.9\%. Ligia F. Guerreiro et al. [33] treated sugarcane vinasse using a combination of coagulation/ flocculation and Fenton's oxidation, and COD removal efficiency was $69.2 \%$. Jaime Martin-Pascual et al. [40] studied the MBBR-MBR technology under $10 \mathrm{~h}$ and $24 \mathrm{~h}$ of HRT and three filling ratios $(20 \%, 35 \%$, and $50 \%$ ) at temperatures between $2.5^{\circ} \mathrm{C}$ and $17.3^{\circ} \mathrm{C}$, and COD removal was ultimately $86.4 \%$. Weihua Sun et al. [43] proposed a new AOP that couples electron beam radiation and MBR treatment to treat real textile effluents containing polyvinyl alcohol, and COD removal was enhanced to $45 \%$ at the end of the research. Xu et al. [44] use the combined MBR-NF Fenton method to treat garbage leachate, the removal rate of COD was $79.6 \%$.

The results further verify that the combined FentonMBR method as a wastewater treatment process can effectively degrade synthetic organic compounds in highly concentrated organic wastewater. In this paper, the removal rate of COD is higher than the results reported by $\mathrm{Xu}$ et al. [26], and similar to the results reported by Perez et al. [27]. The Fenton process has the advantages of high oxidation capacities and unselectivity of pollutants, and it can oxidate the high concentration of pollutants quickly and efficiently. Advantages of the MBR process are low effluent concentration of organic matter and suspended solids, as well as the small area of sewage treatment facilities. Combining the merits of the two processes, a new method has been formed to remove the high concentration organic wastewater effectively. This work exerted the advantages of combining the Fenton and MBR process to deal with synthetic pollutants. The concrete principle is that some organic compounds such as polyethylene glycol and surfactants can be broken to little pieces by Fenton oxidation, and subsequently treated by the MBR process, thus the method is efficient and economical, and the results are consistent with that of Sanchez et al. [28].

\section{Conclusions}

The results of this study show that the combined Fenton and MBR process was successfully used to treat cutting fluid wastewater. Meanwhile, the operating parameters, including initial $\mathrm{pH}$, reaction temperature, treatment time, $\mathrm{Fe}^{2+}$ dosage, $\mathrm{H}_{2} \mathrm{O}_{2}$ dosage, hydraulic retention time (HRT), and dissolved oxygen (DO) concentration were optimized in detail.

1. The optimum reaction conditions of the Fenton process were: COD concentration of $2,500 \mathrm{mg} / \mathrm{L}$, reaction temperature of $30^{\circ} \mathrm{C}, \mathrm{pH}$ of $3.0, \mathrm{Fe}^{2+}$ dosage of $20 \mathrm{mmol} / \mathrm{L}, \mathrm{H}_{2} \mathrm{O}_{2}$ dosage of $250 \mathrm{mmol} / \mathrm{L}$, and treatment time of $3 \mathrm{~h}$.

2. The optimal parameters of MBR treatment were: HRT of $8 \mathrm{~h}$, dissolved oxygen (DO) concentration of $1 \mathrm{mg} / \mathrm{L}$.

3. Using the Fenton-MBR combined process to treat cutting fluid wastewater operating continuously under the most favorable conditions for seven days, ultimately the removal rate of COD could reach even $97 \%$ under the high influent concentration of $3,000 \mathrm{mg} / \mathrm{L}$, and the effluent COD was reduced to $100 \mathrm{mg} / \mathrm{L}$. The method can provide the theoretical basis and technical reference for the solution of the cutting fluid wastewater and similar problems. 


\section{Acknowledgements}

This project was supported by the National Natural Science Foundation of China (Nos. 41672224 and 41372259) and the Special Fund for Basic Scientific Research of Central Colleges (Chang'an University, 310829153311) and the Open Fund Project of Shaanxi Key Laboratory of Exploration And Comprehensive Utilization of Mineral resources (No. 2014HB002).

\section{References}

1. BRAGA A.F.B., MOREIRA S.P., ZAMPIERI P.R., BACCHIN J.M.G., MEI P.R. New processes for the production of solar-grade poly crystal line silicon: A review. Solar Energy Materials and Solar Cells, 92 (4), 418, 2008.

2. GOETZBERGER A., HEBLING C. Photovoltaic materials, past, present, future. Solar Energy Materials and Solar Cells, $\mathbf{6 2}(1-2), 1,2000$

3. SARYI, D., EINHAUS, R. Silicon feedstock for the multicrystalline photovoltaic industry.Solar Energy Materials and Solar Cells, 72, 27, 2002.

4. ZHAN W., WANG X., Li D., REN Y., LIU D., KANG J. Catalytic wet air oxidation of high concentration pharmaceutical wastewater. Water science and technology, 67 (10), 2281, 2013.

5. MA J.Y., MA Z,Y. Investigation on incineration of salty organic wastewater. International Conference on Bioinformatics \& Biomedical Engineering. ICBBE: 1-4,2009.

6. ZHEN L., MING W., ZHENG J., SU L. Extraction of phenol from wastewater by N-octanoylpyrrolidine. Journal of Hazardous Materials, 114 (1-3), 111, 2004.

7. OFIR E., OREN Y., ADIN A. Comparing pretreatment by iron of electro-flocculation and chemical flocculation. Desalination, 204 (1), 87, 2007.

8. WANG Y.H., GAO C.J., YANG S.K. Research of victoria blue B wastewater by coagulation and co-precipitation. Asian Journal of Chemistry, 26 (12), 3600, 2014.

9. KISHIMOTO N., MORITA Y., TSUNO H., OOMURA T., MIZUTANI H. Advanced oxidation effect of ozonation combined with electrolysis. Water Research, 39 (19), 4661, 2005.

10. AYRANCI E., DUMAN O. Adsorption of aromatic organic acids onto high area activated carbon cloth in relation to wastewater purification. Journal of Hazardous Materials, 136 (3), 542, 2005

11. HUANG Y., WANG L. Application of membrane separation to wastewater treatment. Industrial Water Treatment, 25 (4), $8,2005$.

12. MA J.X., WANG Z.W., XU Y.L., WANG Q.Y., WU Z.C., GRASMICK A. Organic matter recovery from municipal wastewater by using dynamic membrane separation process. Chemical Engineering Journal, 219 (3), 190, 2013.

13. RYOSUKE S., TOSHINARI M., YOICHIRO H., NOBUO N., HIROAKI.I O. Biological treatment of harmful TNT wastewater containing a high concentration of nitrogen compounds by waste activated sludge. Journal of Biotechnology, 150, 226, 2010.

14. WU Z.C., ZHOU M.H., WANG D.H. Synergetic effects of anodic-cathodic electro-catalysis for phenol degradation in the presence of iron (II). Chemosphere, 48 (10),1089, 2002.
15. DECAROLS J., HONG S.K., TAYLOR J. Fouling behavior of a plot scale inside-out hollow fiber UF membrane during dead-end filtration of tertiary wastewater. Journal of Membrane Science, 191 (1-2), 165, 2001.

16. SUN Y., LI Y.W. The technology of wastewater treatment and energy recovery based on UASB reactor. Mechanic Automation and Control Engineering, 8, 4310, 2010.

17. ZHANG Y., YAN L., CHI L. LONG X., MEI Z., ZHANG Z. Startup and operation of anaerobic EGSB reactor treating palm oil mill effluent. Journal of Environmental Sciences, 20 (6), 658, 2008.

18. FUCHS W., BINDER H., MAVRIAS G., BRAUN R. Anaerobic treatment of wastewater with high organic content using a stirred tank reactor coupled with a membrane filtration unit. Water Research, 37 (4), 902, 2003.

19. YIGIT N.O., UZAL N., KOSEOGLU H. HARMAN I., YUKSELER H., YETIS U., CIVELEKOGLU G., KITIS M. Treatment of a denim producing textile industry wastewater using pilot-scale membrane bioreactor. Desalination, 240 (1-3), 143,2009.

20. LESJEAN B., HUISJES E.H. Survey of the European MBR market-trends and perspectives. Desalination, 231 (1-3), 71, 2008.

21. IPEK G., GULERMAM A.S., FILIZ B.D. Importance of $\mathrm{H} 2 \mathrm{O} 2 / \mathrm{Fe} 2+$ ratio in Fenton's treatment of a carpet dyeing wastewater. Journal of Hazardous Materials, 136 (3), 763, 2006.

22. ZAZO J.A., CASAS J.A., MOHEDANOA.F., GILARRANZ, M.A., RODRíGUEZ J.J. Chemical Pathway and Kinetics of Phenol Oxidation by Fenton's Reagent. Environmental Science \& Technology, 39 (23), 9295,2005.

23. YANG D. Physical and oxidation removal of organics during Fenton treatment of matrue municipal landfill leachate. Journal of Hazardous Materials, 146 (1-2), 334, 2007.

24. MARSHALL S.S., INNOCENTIA G.E. Multi-stage EGSB/ MBR treatment of soft drink industry wastewater. Chemical Engineering Journal, 285, 368, 2015.

25. PRETEL R., ROBLES A., RUANO M.V., SECO A., FERRER J. Economic and environmental sustainability of submerged anaerobic MBR-based (AnMBR-based) technology as compared to aerobic-based technologies for moderate-/high-loaded urban wastewater treatment. Journal of Environmental Management, 166, 45, 2015.

26. XU Q.H., HAMID A., WEN X.H., ZHANG B., YANG N.N. Fenton-Anoxic-Oxic/MBR process as a promising process for avermectin fermentation wastewater reclamation. Separation and Purification Technology, 134, 82, 2014.

27. PEREZ J.A.S., CARRA I., SIRTORI C., AGUERA A., ESTEBAN B. Fate of thiabendazole through the treatment of a simulated agro-food industrial effluent by combined MBR/Fenton processes at mg/L scale. Water Research, 51, 55, 2014.

28. PEREZ J.A.S., SANCHEZ I.M.R., CARRA I., REINA A.C., LOPEZ J.L.C., MALATO S. Economic evaluation of a combined photo-Fenton/MBR process using pesticides as model pollutant. Factors affecting costs. Journal of Hazardous Materials, 244-245 (2), 195, 2013.

29. KUO W.G. Decolorizing dye wastewater with Fenton's reagent. Water Research, 26 (27), 881, 1992.

30. KWON B.G., DONG S.L., KANG N., YOON J. Characteristics of pchlorophenol oxidation by Fenton's reagent. Water Research, 33 (9), $2110,1999$.

31. KOCHANY J., LUGOWSKI A. Application of Fenton's reagent and activated carbon for removal of nitrification inhibitors. Environmental Technology, 19 (4), 425, 1998. 
32. KAVITHA V., PALANIYELU K. Destruction of cresols by Fenton oxidation process. Water Research, 39 (13), 3062, 2005.

33. GUERREIRO L.F., RODRIGUES C.S.D., DUDA R.M., OLIVEIRA R.A.O., RUI A.R.B., MADEIRA L.M. Treatment of sugarcane vinasse by combination of coagulation/flocculation and Fenton's oxidation. Journal of Environmental Management, 181, 237, 2016.

34. ABOU-ELELA S.I., ALI M.E.M., IBRAHIM H.S. Combined treatment of retting flax wastewater using Fenton oxidation and granular activated carbon. Arabian Journal of Chemistry, 9 , 511, 2016.

35. FANG S.,WANG C., CHAO B.T. Operating conditions on the optimization and water quality analysis on the advanced treatment of papermaking wastewater by coagulation/Fenton process. Desalination and Water Treatment, 57 (27), 12755, 2015.

36. WEI J., SONG Y.H., MENG X.G., JEAN-STE'PHANE P. Optimization and analysis of homogenous Fenton process for the treatment of dry-spun acrylic fiber manufacturing wastewater. Desalination and Water Treatment, 56, 3036, 2015.

37. VERGILI I., GENCDAL S. Applicability of combined Fenton oxidation and nanofiltration to pharmaceutical wastewater. Desalination and Water Treatment, 56, 3501, 2015.

38. MOUSSAVI M., MATAVOS-ARAMYAN M. Chelatemodified fenton treatment of sulfidic spent caustic. Korean Journal of Chemical Engineering, 33 (8), 2384, 2016.
39. GONZALEZ-PEREZ D.M., PEREZ J.I., NIETO M.Á.G. Carbamazepine behaviour and effects in an urban wastewater MBR working with high sludge and hydraulic retention time. Journal of Environmental Science \& Health Part A Toxic/hazardous Substances \& Environmental Engineering, 51 (10), 855, 2016

40. MARTIN-PASCUAL J., LEYVA-AIAZ J.C., POYATOS J.M. Treatment of urban wastewater with pure moving bed membrane bioreactor technology at different filling ratios, hydraulic retention times and temperatures. Annals of Microbiology , 66, 607, 2016.

41. PATSIOS, S.I., PAPAIOANNOU, E.H., KARABELAS,A.J. Long-term performance of a membrane bioreactor treating table olive processing wastewater. Journal of Chemical Technology and Biotechnology, 91 (8), 2253, 2015.

42. ZHUANG H.F., HAN H.G., SHAN S.D. Treatment of British Gas/Lurgi coal gasification wastewater using a novel integration of heterogeneous Fenton oxidation on coal fly ash/sewage sludge carbon composite and anaerobic biological process. Fuel, 178, 155, 2016.

43. SUN W.H., CHEN J., CHEN L.J.,WANG J.L., ZHANG Y.M. Coupled electron beam radiation and MBR treatment of textile wastewater containing polyvinyl alcohol. Chemosphere, 155, 57, 2016.

44. XU Y.D., FAN L.X., HUANG Y.F. Treatment of waste leachate MBR-NF concentrate by Fenton process. Chinese Journal of Environmental Engineering, 8 (9), 3711, 2014. 
